\title{
FAKTOR-FAKTOR YANG MEMPENGARUHI KEJADIAN KANKER SERVIKS DI RSUD Dr. M. YUNUS BENGKULU TAHUN 2011
}

\author{
Dili Maryani, Elly Wahyuni, Sri Sumiati \\ Poltekkes Kemenkes Bengkulu Jurusan Kebidanan, Jl.Indragiri No.3 Padang Harapan \\ Poltekkes Kemenkes Bengkulu Jurusan Kebidanan,Jl.Indragiri No.3 Padang Harapan \\ Poltekkes Kemenkes Bengkulu Jurusan Kebidanan,Jl.Indragiri No.3 Padang Harapan
}

\begin{abstract}
Cervical cancer is the second deadly disease to the women Dr. M.Yunus hospital recorded 25 cervical cancer cases in 2009, recorded 30 cervical cancer cases in 2010 then increased up to 40 cases in2011. The objective of this research is to recognize in factors which influenee cervical cancer cases in Dr. M.Yunus Hospital in Bengkulu, in 2011. The research was held since July 2012, 2012 to August 12, 2012. The population of this research were all the fertile age women who came to midwifery polyclinic of Dr. M.Yunus hospital in Bengkulu, in 2011. With amount 0 f 3.609 patient but only 40 woman who got cervical cancer. The sampling was takes with the comparison 1:1 that is forty cases total sampling and forty control taken systematically random sampling and case control is used in this research. The data used is secondary data and analized by univariat and bivariat with T-test.Based on the research we found that the average age of fertile women is 43.83 years old, the average age of marriage is 21.53 years old. The maternal parity rate is 2,61 . There is not any difference of age to the cervical cancer cases. There is small difference between the age, of marriage and parity towards cervical cancer in Dr. M. Yunus hospital in Bengkulu in 2011. There is no correlation between hormonal contraception user and cervical cancer case in Dr. M. Yunus hospital.Midwives should improve their knowledge and the society understandings about cervical cancer through seminar.
\end{abstract}

\begin{abstract}
Abstrak : Kanker serviks merupakan penyakit mematikan kedua pada perempuan di rumah sakit Dr M.Yunus tercatat 25 kasus kanker serviks pada tahun 2009, 30 kasus di tahun 2010 kemudian meningkat hingga 40 kasus pada tahun 2011. Tujuan dari penelitian ini adalah untuk mengetahui faktor-faktor yang mempengaruhi kasus kanker serviks di Rumah Sakit Dr M.Yunus di Bengkulu, pada tahun 2011.Penelitian ini dilakukan sejak Juli 2012, mulai tanggal 12 Agustus 2012. Populasi penelitian ini adalah semua wanita usia subur yang datang ke poliklinik kebidanan rumah sakit Dr M.Yunus di Bengkulu, pada tahun 2011. Dengan jumlah pasien 3,609 tetapi hanya 40 wanita yang menderita kanker serviks. Pengambilan sampel mengambil dengan perbandingan 1:1 yaitu empat puluh kasus total sampling dan empat puluh kontrol diambil sampel acak dan sistematis kasus kontrol yang digunakan dalam penelitian ini. Data yang digunakan adalah data sekunder dan dianalisis secara univariat dan bivariat dengan T-test.Berdasarkan penelitian kami menemukan bahwa usia rata-rata wanita subur adalah 43,83 tahun, rata-rata usia pernikahan adalah 21,53 tahun. Tingkat paritas ibu adalah 2,61. Tidak ada perbedaan usia untuk kasus kanker serviks. Ada perbedaan kecil antara usia, perkawinan dan paritas terhadap kanker serviks di Dr M. Yunus rumah sakit di Bengkulu pada tahun 2011. Tidak ada hubungan antara pengguna kontrasepsi hormonal dan kasus kanker serviks di Dr M. Yunus rumah sakit.Bidan harus meningkatkan pengetahuan dan pemahaman masyarakat tentang kanker serviks melalui penyuluhan
\end{abstract}

Kata Kunci: Usia, usia perkawinan, Paritas, pengguna Kontrasepsi Hormonal, Kanker Serviks

Wordl Health Organization (WHO), menyatakan bahwa kanker serviks merupakan penyebab kematian nomor dua di dunia dari seluruh penyakit kanker yang ada. Di Asia Tenggara,Vietnam menduduki urutan pertama kematian karena kanker servik, sedangkan Indonesia dan Filipina menududuki urutan kedua. Di Indonesia diperkirakan 15.000 kasus baru kanker serviks terjadi setiap tahunnya, sedangkan angka kematiannya diperkirakan 7.500 kasus per tahun. Selain itu, setiap harinya diperkirakan terjadi 41 kasus baru kanker serviks dan 20 perempuan meninggal dunia karena kanker serviks (Wijaya, 2010).

Kanker serviks adalah kanker yang terjadi pada servik uterus, suatu daerah pada organ reproduksi wanita yang terletak antara rahim (uterus) dengan liang senggama (Sukaca, 2009). Penyebab langsung 
dari kanker serviks belum diketahui, namun kejadiannya dipengaruhi sejumlah faktor ekstrensik, yang penting meliputi: 1) insidensi lebih tinggi pada mereka yang kawin, terutama pada gadis yang koitus pertama pada usia muda ( $<16$ tahun), 2) tingginya paritas, apalagi jarak persalinan terlampau dekat, 3) sosial ekonomi rendah, 4) berganti-ganti pasangan, 5) wanita yang mengalami infeksi virus HPV (Human Papilloma Virus) tipe 16 atau 18, dan 6) kebiasaan merokok 7) penggunaan kontrasepsi oral (Wiknjosastro, 2005).

Perempuan yang rawan mengidap kanker serviks adalah mereka yang berusia 3550 tahun dan masih aktif berhubungan seksual (prevalensi 5-10\%). Prevalensi atau angka kejadian tertinggi kanker serviks (sekitar 20\%) terutama dijumpai pada perempuan yang telah aktif secara seksual sebelum usia 16 tahun (Wijaya, 2010).

Paritas yang berbahaya adalah dengan memiliki jumlah anak lebih dari 2 orang atau jarak persalinan terlampau dekat, sebab dapat menyebabkan timbulnya perubahan sel-sel abnormal pada mulut rahim. Penggunaan kontrasepsi pil dalam jangka waktu lama (5 tahun atau lebih) meningkatkan risiko kanker leher rahim sebanyak 2 kali WHO melaporkan risiko relatif pada pemakaian kontrasepsi oral sebesar 1,19 kali dan meningkat sesuai dengan lamanya pemakaian (Sukaca, 2009).

Penelitian Suhartini (2010) di RSUD Soeroto Ngawi menunjukkan bahwa ada hubungan usia menikah dan paritas dengan kejadian kanker serviks. Khasbiyah (2004) di Rumah Sakit Dokter Kariadi Semarang me-nunjukkan bahwa ada hubungan yang ber-makna antara paritas dan umur pertama kali melakukan hubungan seksual dengan kejadian kanker serviks uteri. Penelitian Azis, dkk (2002) tentang deteksi human papilloma virus (HPV) tipe 16 dengan teknik polymerase chain reaction (PCR) pada kanker serviks uteri menunjukkan bahwa 43,3\% pasien menderita kanker servik berumur $\geq 50$ tahun, $70 \%$ umur pertama kawin $<20$ tahun, $50 \%$ de- ngan paritas $\geq 5$ dan $56,66 \%$ menggunakan kontrasepsi hormonal.

Penelitian Tresna, dkk (2005) tentang deteksi human papilloma virus (HPV) pada sediaan sitologi papanicolaou smear lesi serviks: suatu uji diagnostic menunjukkan hasil bahwa penderita kanker serviks $46,5 \%$ berusia $30-39,67,0 \%$ usia pertama kali hubungan $\leq 20$ tahun, $83,9 \%$ dengan paritas multipara dan $62,4 \%$ menggunakan kontrasepsi IUD. Hasil penelitian Andrijono (2010) tentang distribusi Usia, Stadium dan Histopatologi Kanker Serviks; Studi Restrospektif pada Pa-sien $\mathrm{Ru}-$ mah Sakit Umum Pusat Nasional Dr. Cipto Mangunkusumo, Jakarta Indonesia menunjukkan bahwa sebagian besar insiden terjadi pada kelompok usia 35-64 tahun $(87,3 \%)$.

Data di RSUD M. Yunus Bengkulu pada tahun 2009 angka kejadian kanker serviks sebanyak 25 orang, tahun 2010 sebanyak 30 orang dan pada tahun 2011 meningkat menjadi 40 orang $(1,10 \%)$. Survey awal yang dilakukan peneliti pada bulan Mei 2012, dari 10 orang yang menderita kanker serviks, 7 orang berusia $>55$ tahun, 4 orang dengan usia menikah < 20 tahun, 5 dengan paritas grandemultipara dan 6 menggunakan kontrasepsi hormonal.

\section{BAHAN DAN CARA}

Jenis penelitian ini menggunakan survey analitik dengan desain case control yaitu penelitian analitik yang menyangkut bagaimana faktor risiko dipelajari dengan menggunakan pendekatan retrospective (Notoatdmojo, 2010). Populasi dalam penelitian ini adalah seluruh wanita usia subur yang datang ke poli RSUD M.Yunus Bengkulu tahun 2011 berjumlah 3.609 orang dan yang menderita kanker serviks berjumlah 40 orang. Sampel penelitian sebesar 80 responden terdiri dari 40 kasus yaitu yang menderita kanker serviks diambil secara total sampling dan 40 kontrol yaitu WUS yang diambil secara systematic random sampling 
Teknik Pengumpulan data pada penelitian ini adalah menggunakan data sekunder. Data sekunder adalah data wanita usia subur yang meliputi: usia, usia menikah, paritas dan penggunaan kontrasepsi hormonal serta diagnosa kanker serviks yang diperoleh dari buku register dan catatan medical record RSUD M. Yunus Bengkulu tahun 2011.
Pengolahan data dilakukan dengan analisa univariat dan bivariat menggunakan uji $\mathrm{T}$ Independen (T-Test Independent) dan chi-square $\left(\mathrm{x}^{2}\right)$.

\section{HASIL}

Analisis univariat dapat dilihat pada tabel di bawah ini :

Tabel .1. Rata-rata Usia, Usia Menikah dan Paritas WUS di RSUD Dr. M. Yunus Bengkulu Tahun 2011

\begin{tabular}{lccccc}
\hline \multicolumn{1}{c}{ Variabel } & N & $\begin{array}{c}\text { Mean } \\
\text { Median }\end{array}$ & SD & $\begin{array}{c}\text { Minimal- } \\
\text { maksimal }\end{array}$ & 95\% CI \\
\hline Usia & 80 & 43,83 & 9,728 & $22-70$ & $41,66-45,99$ \\
Usia Menikah & 80 & 21,53 & 3,962 & $15-38$ & $20,64-22,41$ \\
& & 20,00 & & & $2,35-2,87$ \\
Paritas & 80 & 2,61 & 1,175 & $0-6$ & \\
& & 2,00 & & & \\
\hline
\end{tabular}

Berdasarkan tabel 1. diatas bahwa rata-rata usia WUS adalah 43,83 tahun dengan standar deviasi 9,728. Rata-rata usia menikah adalah 21,53 tahun dengan stan-dar deviasi 3,962. Rata-rata paritas ibu adalah 2,61 dengan standar deviasi 1,175 .

Tabel 2. Frekuensi Pengguna Alat Kontrasepsi Hormonal di RSUD Dr. M. Yunus Bengkulu Tahun 2011

\begin{tabular}{lcc}
\multicolumn{1}{c}{$\begin{array}{c}\text { Variabel } \\
\text { Penggunaan Alat Kontrasepsi }\end{array}$} & $\begin{array}{c}\text { Frekuensi } \\
(\mathbf{n = 8 0})\end{array}$ & $\begin{array}{c}\text { Persentase } \\
(\boldsymbol{\%})\end{array}$ \\
\hline Menggunakan & 67 & 83,8 \\
Tidak Menggunakan & 13 & 16,3 \\
\hline
\end{tabular}

Berdasarkan tabel 2. Diatas menunjukkan bahwa hampir seluruh respon- den $(83,8 \%)$ menggunakan alat kontrasepsi.

Tabel 3. Pengaruh Usia, Usia Menikah dan Paritas dengan Kejadian Kanker Serviks di RSUD Dr. M. Yunus Bengkulu Tahun 2011

\begin{tabular}{|c|c|c|c|c|c|}
\hline Variabel & Mean & SD & $\mathbf{S E}$ & $P$ value & $\mathbf{N}$ \\
\hline \multicolumn{6}{|l|}{ Usia } \\
\hline Kanker Serviks & 45,85 & 10,106 & 1,598 & 0,062 & 40 \\
\hline Tidak Kanker Serviks & 41,80 & 9,008 & 1,424 & & 40 \\
\hline \multicolumn{6}{|l|}{ Usia Menikah } \\
\hline Kanker Serviks & 19,83 & 2,591 & 0,410 & 0,000 & 40 \\
\hline Tidak Kanker Serviks & 23,23 & 4,376 & 0,692 & & 40 \\
\hline \multicolumn{6}{|l|}{ Paritas } \\
\hline Kanker Serviks & 3,30 & 1,091 & 0,172 & 0,000 & 40 \\
\hline Tidak Kanker Serviks & 1,93 & 0,797 & 0,126 & & 40 \\
\hline
\end{tabular}

Hasil uji statistik didapatkan nilai $\mathrm{p}=$ 0,062 berarti pada alpha $5 \%$ terlihat tidak ada pengaruh rata-rata usia WUS dengan kejadian kanker serviks di RSUD Dr. M. Yunus Bengkulu Tahun 2011.

Hasil uji statistik didapatkan nilai $\mathrm{p}=$ 0,000 berarti pada alpha $5 \%$ terlihat ada pengaruh rata-rata usia menikah WUS dengan kejadian kanker serviks di RSUD Dr. M. Yunus Bengkulu Tahun 2011.

Hasil uji statistik didapatkan nilai $\mathrm{p}=$ 0,000 berarti pada alpha 5\% terlihat ada pengaruh rata-rata paritas WUS dengan 
kejadian kanker serviks di RSUD Dr. M. $\quad$ Yunus Bengkulu Tahun 2011.

Tabel 4. Hubungan Pengguna Kontrasepsi Hormonal dengan Kejadian Kanker Serviks di RSUD Dr. M. Yunus Bengkulu Tahun 2011

\begin{tabular}{|c|c|c|c|c|c|}
\hline \multirow{3}{*}{$\begin{array}{c}\text { Variabel } \\
\text { Penggunaan Alkon }\end{array}$} & \multicolumn{4}{|c|}{ Kanker Serviks } & \multirow{3}{*}{$P$ value } \\
\hline & \multicolumn{2}{|c|}{ Kanker Serviks } & \multirow{2}{*}{$\begin{array}{r}\begin{array}{r}\text { Tidak } \\
\text { Servik }\end{array} \\
\mathbf{n}\end{array}$} & \multirow{2}{*}{$\begin{array}{c}\text { Kanker } \\
\%\end{array}$} & \\
\hline & $\mathbf{n}$ & $\%$ & & & \\
\hline Menggunakan & 36 & 90 & 31 & 77,5 & \\
\hline Tidak Menggunakan & 4 & 10 & 9 & 22,5 & 0,225 \\
\hline Jumlah & 40 & 100 & 40 & 100 & \\
\hline
\end{tabular}

Tabel diatas menunjukkan bahwa dari 40 orang responden yang menggunakan alat kontrasepsi ada 36 orang $(90 \%)$ menderita kanker serviks. Hasil analisis menunjukkan bahwa nilai $\mathrm{p}=0,225$ yang lebih kecil dari alpha, berarti tidak ada hubungan yang bermakna antara pengguna kontrasepsi hormonal dengan kejadian kanker serviks di RSUD Dr. M. Yunus Bengkulu Tahun 2011.

\section{PEMBAHASAN}

Pengaruh Usia dengan Kejadian Kejadian Kanker Serviks di RSUD Dr. M.Yunus Bengkulu Tahun 2011

Hasil penelitian ini menunjukkan bahwa rata-rata usia ibu menderita kanker serviks adalah 45,85 tahun. Dilihat dari usia penderita, penyakit kanker serviks ratarata dialami pe-rempuan pada rentang 40 sampai 50 tahun. Dengan perhitungan masa inkubasi 7-10 tahun, berarti penderita mulai terjangkit human papilloma virus (HPV), penyebab kanker serviks, pada usia produktif, yaitu sekitar 30 sampai 40 tahun (Suryana, 2011). Begitu juga Nadia (2009), menunjukkan bahwa penderita kanker serviks tertinggi pada kelompok usia 45-54 tahun $(39 \%)$.

Hasil analisis uji statistik juga didapatkan tidak ada pengaruh usia dengan kejadian kanker serviks. Risiko terjadinya kanker meningkat 2 kali lipat setelah usia 35 hingga 60 tahun. Meningkatnya risiko kanker pada usia lanjut merupakan gabungan dari meningkatnya dan bertambah lamanya waktu pemaparan terhadap karsinogen serta makin melemahnya system kekebalan tubuh akibat usia. Hal ini sejalan dengan Tresna dkk (2009), hasil penelitian menunjukkan bahwa sebagian besar 46,5\% lesi serviks berada pada rentang usia 40-49 tahun.

Hasil ini bertolak belakang dengan penelitian Azis, dkk (2002) tentang deteksi human papilloma virus (HPV) tipe 16 dengan teknik polymerase chain reaction $(\mathrm{P}-$ CR) pada kanker serviks uteri menunjukkan bahwa 43,3\% pasien menderita kanker servik berumur $\geq 50$ tahun.

Begitu juga dengan Wijaya (2010), perempuan yang rawan mengidap kanker serviks adalah mereka yang berusia $35-50$ tahun dan masih aktif berhubungan seksual (prevalensi 5-10\%). Meski fakta memperlihatkan bahwa terjadi pengurangan risiko infeksi HPV seiring pertambahan usia, namun sebaliknya risiko infeksi menetap /persisten justru meningkat. Hal ini diduga karena seiring pertambahan usia, terjadi perubahan anatomi (retraksi) dan histology (metaplasia). Menurut Sukaca (2009), pada usia 35-55 tahun memiliki risiko 2-3 kali lipat untuk menderita kanker serviks. Semakin tua umur seseorang akan mengalami proses kemunduran. Pada masa ini sering terjadi perubahan sel-sel abnormal pada mulut rahim.

Pengaruh Usia Menikah dengan Kejadian Kejadian Kanker Serviks di RSUD Dr. M.Yunus Bengkulu Tahun 2011

Hasil penelitian menunjukkan rata-rata usia menikah adalah 21,53 tahun. Hasil penelitian ini sesuai dengan Joeharno (2008), bahwa umur pertama kali menikah merupakan faktor risiko terhadap kejadian kanker leher rahim dengan besar risiko 2,54 
kali, untuk mengalami kanker leher rahim pada perempuan yang melaksanakan perkawinan pada usia $<20$ tahun disbandingkan dengan perkawinan pada usia $>20$ tahun. Usia saat perkawinan $<20$ tahun erat kaitannya dengan aktivitas seksual. Masuknya benda asing dalam tubuh perempuan, termasuk alat kelamin laki-laki dan sel sperma, akan mengakibatkan perkembangan sel ke arah abnormal. Infeksi dalam rahim dengan mudah terjadi apabila timbul luka akibat masuknya benda asing tersebut. Sel abnormal dalam mulut rahim tersebut dapat mengakibatkan kanker mulut rahim. Kanker leher rahim menyerang alat kandungan perempuan berawal dari mulut rahim dan berisikomenyebar ke vagina hingga ke luar di permukaan (Admin, 2008).

Hasil penelitian ini menunjukkan ada pengaruh usia menikah dengan kejadian kanker serviks. Hal ini mungkin terkait dengan komplemen histon pada semen yang bertindak sebagai antigen, kematangan sistim imun terutama mukosa serviks sendiri, rentan waktu kesempatan berganti partner seksual yang terkait dengan risiko terkena infeksi. Faktor risiko ini dihubungkan dengan karsinogen pada zona transformasi yang sedang berkembang dan paling berbahaya apabila terinfeksi HPV pada 5-10 tahun setelah menarche (Antara dkk, 2008). Perempuan yang menikah di usia 20 tahun berisiko terkena kanker leher rahim, oleh karena pada usia tersebut sel-sel leher rahim belum matang. Terpaparnya rahim 40 terhadap Human Papiloma Virus (HPV) akan mengakibatkan pertumbuhan sel menyimpang menjadi kanker (Hendriana, 2008). Leher rahim terdiri dari dua lapis epitel yaitu squa-mosa dan kolumner, pada sambungan kedua epitel tersebut terjadi pertumbuhan yang aktif terutama pada usia muda. Epitel kolumner akan berubah menjadi epitel skuamosa. Perubahan tersebut disebut metaplasia, jika HPV menempel, perubahan menyimpang menjadi displasia yang merupakan awal dari kanker (Hendriana,2008). Hubungan atau kontak seksual pada usia di bawah 17 tahun me- rangsang tumbuhnya sel kanker pada alat kandungan perempuan, pada rentang usia 12 hi-ngga 17 tahun perubahan sel dalam mulut ra-him lebih aktif. Ketika sel sedang membelah secara aktif (metaplasi) seharusnya tidak ter-jadi kontak atau rangsangan apapun dari luar.

Penelitian ini sesuai dengan Wijaya (20-10), bahwa prevalensi atau angka kejadian tertinggi kanker serviks (sekitar $20 \%$ ) terutama dijumpai pada perempuan yang telah aktif secara seksual sebelum usia 16 tahun. Hubungan seksual pada usia terlalu dini bisa meningkatkan risiko terserang kanker serviks dua kali lebih besar dibandingkan perempuan yang melakukan hubungan seksual setelah usia 20 tahun. Salah satu alasan untuk risiko ini yaitu bahwa sel-sel yang sedang tumbuh di dalam serviks pada wanita muda lebih rentan dari pada sel-sel serviks dewasa pada wanita yang lebih tua dan lebih mudah dirusak oleh luka kecil yang disebabkan seringnya berhubungan seksual. Menurut Sukaca (2009), pada usia muda, sel-sel rahim masih belum matang. Sel-sel tersebut tidak rentan terhadap zat-zat kimia yang dibawa oleh sperma, dan segala macam perubahannya. Jika belum ma-tang, bisa saja ketika ada rangsangan sel yang tumbuh tidak seimbang dengan sel yang mati, dengan begitu maka kelebihan sel ini bisa be-rubah sifat menjadi sel kanker. Berbagai pen-elitian menunjukkan bahwa terdapat hu-bungan yang bermakna antara lesi prakanker dan kanker serviks dengan aktivitas seksual pada usia dini, khususnya sebelum umur 17 tahun. Faktor risiko ini dihubungkan dengan karsinogen pada zona transpormasi yang sedang berkembang dan paling berbahaya apabila terinfeksi HPV pada 5-10 tahun setelah menarke (Suwiyoga, 2007). Begitu juga dengan penelitian Hetiningtyas (2006), ada hubungan yang bermakna antara usia menikah dengan kejadian kanker serviks di RSUUSD Gambiran Kediri. 


\section{Pengaruh Paritas dengan Kejadian Ke- jadian Kanker Serviks di RSUD Dr. M. Yunus Bengkulu Tahun 2011}

Hasil penelitian menunjukkan rata-rata paritas ibu adalah 2,61 dengan standar deviasi 1,175. Bahwa paritas merupakan faktor risiko terhadap kejadian kanker leher rahim dengan besar risiko 4,55 kali untuk terkena kanker serviks pada perempuan dengan paritas > 3 dibandingkan perempuan dengan paritas $\leq 3$.

Hasil penelitian ini menunjukkan ada pengaruh paritas dengan kejadian kanker serviks. Hasil penelitian ini sejalan dengan Pe-nelitian yang dilakukan oleh Suhartini (2010) menunjukkan bahwa ada hubungan usia menikah dan paritas dengan kejadian kanker serviks. Penelitian yang dilakukan oleh Khasbiyah (2004) menunjukkan bahwa ada hubungan yang bermakna antara paritas dengan kejadian kanker serviks uteri. Perempuan dengan paritas tinggi terkait dengan terjadinya eversi epitel kolumner serviks selama kehamilan yang menyebabkan dinamika baru epitel metaplastik imatur yang dapat meningkatkan risiko transformasi sel serta trauma pada serviks sehinggaterjadi infeksi HPV persisten. Hal ini dibuktikan pada suatu studi kohort dimana didapatkan bahwa infeksi HPV lebih mudah ditemukan pada wanita hamil dibandingkan yangtidak hamil. Selain itu, pada kehamilan terjadi penurunan kekebalan seluler (Sawaya dkk, 2003; Moodley dkk, 2003). Peneliti lain juga menyatakan bahwa pada kehamilan, progesteron dapat menginduksi onkogen HPV menjadi stabil sehingga terjadi integrasi DNA virus ke dalam genom sel penjamu dan menurunkan kekebalan mukosa zona transformasi (Schift dkk, 2000). Selain itu, pada kehamilan risiko, terjadinya infeksi dan progresiinfeksi lebih tinggi terkait dengan eversi serviks akibat pengaruh estrogen (Antara dkk, 2008).

Hasil ini juga sejalan dengan Wijaya (2010), sama seperti jumlah partner seksual, jumlah kehamilan yang pernah dialami wanita juga meningkatkan risiko terjadinya kanker serviks. Sehingga, wanita yang mempunyai banyak anak atau sering melahirkan mempunyai risiko terserang kanker serviks lebih besar. Menurut Sukaca (2009), paritas yang berbahaya adalah dengan memiliki jumlah anak lebih dari 2 orang atau jarak persalinan terlampau dekat, sebab dapat menyebabkan timbulnya perubahan sel-sel abnormal pada mulut rahim. Jika jumlah anak yang dilahirkan melalui jalan normal banyak dapat menyebabkan terjadinya perubahan sel abnormal dari epitel pada mulut rahim dan dapat berkembang menjadi keganasan. Paritas lebih dari 5 akan meningkatkan resiko terjadinya kanker serviks sebesar 3 kali. Eversi epitel kolumner selama kehamilan menyebabkan di-namika baru epitel metaplasia imatur sehingga meningkatkan transformasi sel. Infeksi HPV lebih mudah ditemukan pada perempuan hami dibandingkan yang tidak hamil terkait dengan terjadinya penurunan seluler pada perempuan hamil. Pada kehamilan, progesterone dapat menginduksi onkogen HPV menjadi stabil sehingga terjadi integrasi DNA virus ke dalam genom sel penjamu dan menurunkan kekebalan mikosa zona transpormasi Hal ini akan dapat menjelaskan peningkatan risiko dysplasia serviks pada paritas yang semakin tinggi (Suwiyoga, 2007).

\section{Hubungan Penggunaan Kontrasepsi Hor- monal dengan Kejadian Kejadian Kanker Serviks di RSUD Dr. M.Yunus Bengkulu Tahun 2011}

Hasil penelitian menunjukkan hampir seluruh responden $(83,8 \%)$ menggunakan alat kontrasepsi. Hal ini menunjukkan bahwa responden menggunakan alat kontrasepsi untuk mencegah kehamilan dan mengatur jarak kehamilan. Akseptor keluarga berencana adalah pasangan usia subur (PUS) yang menggunakan salah satu alat/obat kontrasepsi (BKKBN, 2007).

Hasil penelitian menunjukkan tidak ada hubungan yang bermakna antara penggunaan kontrasepsi hormonal dengan kejadian kejadian kanker serviks. Hasil penelitian ini tidak memberikan hubungan dapat disebabkan karena sampel yang 
terlalu sedikit, tidak didapatkan lamanya pemakaian $\mathrm{KB}$ hormonal dan dikarenakan keterbatasan peneliti baik waktu, tenaga dan biaya serta variable ini sebaiknya menggunakan data primer.

Hasil penelitian ini bertolak belakang dengan Herman (1998), Pemakaian estrogen dapat berisiko karena merangsang penebalan dinding endometrium dan merangsang sel-sel endometrium sehingga berubah sifat menjadi kanker. Penggunaan hormon estrogen harus dalam pengawasan dokter agar sekaligus diberikan zat anti kanker, sehingga tidak berkembang menjadi kanker. Begitu juga dengan Suwiyoga (2007), peranan kontrasepsi hormonal khususnya pil dapat mengaktivasi proses metaplasia dimana pil kontrasepsi dapat menginduksi eversi epitel kolumner sehingga meningkatkan terjadinya atipia dan dapat me-nurunkan kadar asam folat darah sehingga ter-jadi perubahan megalobastik pada sel epitel serviks. Kontrasepsi oral dalam jangka panjang lebih dari 4 tahun dapat meningkatkan risiko kanker serviks uteri 1,5-2,5 kali. Menurut Sukaca (2009), penggunaan kontrasepsi pil dalam jangka waktu lama (5 tahun atau lebih) meningkatkan risiko kanker leher rahim sebanyak 2 kali WHO melaporkan risiko re-lative pada pemakaian kontrasepsi oral se-besar 1,19 kali dan meningkat sesuai dengan lamanya pemakaian. Menurut Wijaya (2010), penggunaan kontrasepsi pil (kombinasi estrogen dan progesterone) dalam jangka waktu lama, yakni 5 tahun atau lebih dapat meni-ngkatkan risiko kanker serviks dua kali lipat lebih besar.

\section{KESIMPULAN}

Kesimpulan penelitian ini : rata-rata usia ibu adalah diantara 41,66 sampai 45,99, rata-rata usia menikah ibu adalah diantara 20,64 sampai 22,41 , rata-rata paritas ibu adalah diantara 2,35 sampai 2,87 dan ham-

\section{DAFTAR KEPUSTAKAAN}

Andrijono, 2007, Vaksinasi HPV Merupakan Pencegahan Primer Kanker Serviks, Majalah pir seluruh responden $(83,8 \%)$ menggunakan alat kontrasepsi. Tidak ada pengaruh usia dengan kejadian kejadian kanker serviks di RSUD Dr. M.Yunus Bengkulu Tahun 2011. Ada pengaruh usia menikah dengan kejadian kejadian kanker serviks di RSUD Dr. M.Yunus Bengkulu Tahun 2011. Ada pengaruh paritas dengan kejadian kejadian kanker serviks di RSUD Dr. M.Yunus Bengkulu Tahun 2011. Tidak ada pengaruh pengguna kontrasepsi hormonal dengan kejadian kejadian kanker serviks di RSUD Dr. M.Yunus Bengkulu Tahun 2011.

Saran bagi RSUD Dr. M. Yunus Bengkulu : meningkatan pengetahuan dan pemahaman masyarakat tentang kanker serviks melalui penyuluhan terhadap masyarakat yaitu : bagi wanita remaja hendaknya menikah diatas usia 20 tahun, Bagi wanita usia reproduktif dalam menggunakan alat kontrasepsi hormonal harus diselingi dengan alat kontrasepsi yang tidak mengandung hormon karena semakin lama menggunakan alkon hormonal semakin tinggi resiko terkena kanker serviks, Bagi wanita usia subur batasi jumlah anak karena semakin banyak paritas semakin tinggi resiko terkena kanker serviks, Bagi wanita yang sudah aktif berhubungan seksual harus sering melakukan deteksi dini kanker serviks seperti melakukan pap smear dan imunisasi HPV. Penanganan lebih lanjut terhadap kejadian kanker serviks melalui penyebaran informasi kepada ibu rumah tangga dimana informasi tersebut merupakan upaya untuk merendahkan angka kehamilan.

Bagi peneliti lain, untuk penelitian lebih lanjut tentang faktor-faktor lain yang mempengaruhi kejadian kanker serviks yaitu variabel merokok, multipatner sex, penggunaan pembersih vagina, riwayat penyakit kelamin dan pola makan serta menggunakan data primer.

Kedokteran Indonesia, Volum: 57, Nomor: 5, Mei 2007

Andrijono, dkk, 2010, Distribusi Usia, Stadium Dan Histopatologi Kanker Serviks; Studi Restrospektif Pada Pasien Rumah Sakit 
Umum Pusat Nasional Dr. Cipto Mangunkusumo, Jakarta Indonesia, 20062010, Majalah Obstetri dan Ginekologi Indonesia Volume 35 Nomor 1 Januari 2011

Azis, dkk, 2002, Deteksi Human Papilloma Virus (HPV) Tipe 16 Dengan Teknik Polymerase Chain Reaction (PCR) Pada Kanker Serviks Uteri, Majalah Obstetri dan Ginekologi Indonesia Volume 29 Nomor 1 Januari 2005

Dianada, R, 2008, Mengenal Seluk Beluk Kanker, Katahati, Yogyakarta

Hetiningtyas, 2006, Hubungan Usia Nikah dengan Kejadian Ca Serviks Periode 1 Januari 2006 s/d 31 Desember 2006 di BKIA RSUUSD Gambiran Kota Kediri, Jurnal Kesehatan Volume 6 No 2 Nopember 2008

Notoatmodjo, 2005, Ilmu Kesehatan Masyarakat, Rineka Cipta, Jakarta

2010, Metodologi Penelitian Kesehatan, Rineka Cipta, Jakarta

Suhartini, 2010, Hubungan Antara Usia Menikah Dan Paritas Dengan Kejadian Kanker Serviks Di RSUD Dr. Soeroto Ngawi, Jurnal Penelitian Kesehatan Suara Forikes Volume 1 Nomor 1 Januari 2010
Sukaca, 2009, Cara Cerdas Menghadapi Kanker Serviks (Leher Rahim), Genius Publisher, Yogyakarta

Suryana, 2011, Tiap Jam Satu Penderita Kanker Serviks di Indonesia Meninggal http://www.mediaindonesia.com

Tresna, ddk (2005), Deteksi Human Papilloma Virus (HPV) Pada Sediaan Sitologi Papanicolaou Smear Lesi Serviks: Suatu Uji Diagnostic, Majalah Obstetri dan Ginekologi Indonesia Volume 33 Nomor 1 Januari 2009

Wijaya, 2010, Pembunuh Ganas itu Bernama Kanker Serviks, Sinar Kejora, Yogyakarta

Wiknjosastro, 2005, Ilmu Kandungan, Yayasan Bina Pustaka Sarwono Prawirohardjo, Jakarta

Yuliantin, 2011, Cegah dan Tangkal Kanker Serviks, Tibbun Media, Surabaya 